\title{
The Total Mobility of the Dime Novel Detective
}

Christian Huck

published in: Perspectives on Mobility. Eds. Ingo Berensmeyer and Christoph Ehland. Amsterdam, New York: Rodopi, 2013, 31-49.

link: http://www.rodopi.nl/senj.asp?BookId=SPATIAL+17

\section{Britain and the Novel}

After travelling through Britain in the 1770s, Georg Christoph Lichtenberg thought he had found the reason why England had given birth to the new literary genre of the novel - and why Germany failed in producing anything alike:

Unsere Lebensart ist nun so simpel geworden, und all unsere Gebräuche so wenig mystisch; unsere Städte sind meistens so klein, das Land so offen, alles ist sich so einfältig treu, daß ein Mann, der einen deutschen Roman schreiben will, fast nicht weiß, wie er Leute zusammen bringen, oder Knoten schürzen soll.

Our way of life has become so simple now, and all our customs so free of mystery; most of the time, our cities are so small, the country so wide, everything stays so much the same, that a man who wants to write a German novel hardly knows how to bring people together, or tie knots. (1817: 56)

In Germany, Lichtenberg reasons, the lack of urbanity and the sparsely populated provinces do not allow for those heterogeneous encounters between strangers that set in motion the contingent plot of a novel. The novel, here, is less a medium for individual self-reflection within the close confines of the mind, but a public space where the double contingency of modern life can be observed. In a modern, mobile society people have to find ways of dealing with others whose origins, thoughts and habits they do not know - and the novel helps the reader to come to terms with this modern condition.

For Lichtenberg, the lack of experienceable contingency in Germany, and consequently the lack of possible plotlines, is determined, first of all, by a lack of spatial mobility:

Für's erste, wenn ein Mädchen mit ihrem Liebhaber aus London des Abends durchgeht, so kann sie in Frankreich sein, ehe der Vater aufwacht, oder in Schottland, ehe er mit seinen Verwandten zum Schluß kommt; daher ein Schriftsteller weder Feen, noch Zauberer, noch Talismane nöthig hat, um die Verliebten in Sicherheit zu bringen; denn wenn er sie nur bis nach Charingcroß oder Hydepark-Corner bringen kann, so sind sie [...] sicher [...]. Hingegen in Deutschland, wenn auch der Vater den Verlust seiner Tochter erst den dritten Tag gewahr würde, wenn er nur weiß, daß sie mit der Post gegangen ist, so kann er sie zu Pferde immer noch auf der dritten Station wieder kriegen. 
Firstly, when a maid and her lover run away from London in the evening, they could be in France before the father awakes, or in Scotland before their relatives understand what happened; therefore, a writer needs neither fairies, nor magicians nor any lucky charms to bring the lovers to safety; because if he can only get them to Charing Cross or Hydepark Corner they are [...] safe [...]. In Germany, however, even if the father would only realize the loss of his daughter on the third day, it would be enough to know that they took the stagecoach in order to catch them by horse at the third station. (59)

While in Germany, apparently, everyone stayed close to home and everything the same, it is the superior English system of stagecoaches and other forms of transportation that, according to Lichtenberg, opened the space of and for the novel and that made possible those unforeseen disappearances and encounters which are necessary for a plot to evolve. Where German writers still had to resort to otherworldly fairies and magic to bring about change, British writers could rely on new technologies and networks of transport to represent contingency.

On the basis of this account by Lichtenberg, Deidre Shauna Lynch (2005), in her recent revision of the emergence of the novel in eighteenth-century Britain, has emphasized that not only the protagonists of the novels were constantly on the road (Tom Jones, Roderick Random, Moll Flanders etc.), but that the books themselves became mobile entities, distributed through the postal system and carried around in pockets and bags. The emergence of the novel, she claims, is connected to the emergence of a mobile society: people travel and meet yet-unknown people and situations - and if people do not travel, books bring yetunknown characters and situations to wherever people are. In novels, and through novels, people could learn how to come to terms with strangers and other unforeseeable situations.

Books were surely not the only, and probably not the most important goods circulating through Britain in the eighteenth century. Improvements in transportation, through the construction of canals, turnpike trusts and similar devices, played an important role in the process of industrialization, bringing raw materials to manufacturers and goods to consumers: even more than people, goods were travelling. Novel writers were very much alert to these developments, and they even used these new consumer goods as protagonists for their novels. These so-called it-narratives featured waistcoats, pins, corkscrews, coaches and similar goods as their central "characters" (Blackwell 2007: 10). The goods changed hands frequently and were put to new uses over and over again; novels report of these ever-new encounters and processes of adaptation to new circumstances. Most importantly, goods are present when humans feel unobserved, and consequently they can transcend the "social intransparency" (Heyl 2004: 258) that is typical for a modern society blighted with double contingency: goods can go where no human would be allowed, e.g. private closets, and are allowed to overhear conversations that where meant to remain private. It-narratives gave a narrative form to the new mobility of modern society - and they managed to overcome the contingency that comes with this new mobility.

However, not only human protagonists were still limited in their mobility (geographical, social and otherwise), but also the mobility of a waistcoat or some other consumer good was restricted due to barriers erected by gender, class, race, religion, profession and politics, as well as regionally differing modes and customs, and finally also individual preferences. But while the mobility of people and goods might have been restricted in various ways, there was, however, one thing that could move freely and unrestricted through social and geographical space, one thing that no one would reject, nowhere - one thing that would be invited to one's home by everyone, and loved. Every rank, every gender, creed or ethnicity in every British 
region accepted coins. Since the establishment of the Bank of England at the end of the seventeenth century, money was able go everywhere, visit everyone, and be exchanged for everything. The mobility of a coin, consequently, was almost total. Consequently, the coin could report from every home and every street in Britain and beyond. The "Adventures of a Guinea", as they are described in a mid-eighteenth-century novel, therefore, are without any limits, as the title claims: Chrysal: Or, the Adventures of a Guinea. Wherein Are Exhibited Views of Several Striking Scenes, with Curious and Interesting Anecdotes of the Most Noted Persons in Every Rank of Life, Whose Hands It Passed through, in America, England, Holland, Germany and Portugal (Johnstone 1760). With money, mobility (geographical, social and otherwise) becomes total. However, whereas printed money became more and more widespread, printed stories about money did never catch on. Novels, it appears, could not match the total mobility of money. Or could they?

\section{The USA and the Dime Novel}

About a hundred years after Lichtenberg had travelled through Britain by coach, the USA established its own system of transportation. In 1869, the Union Pacific and the Central Pacific completed the first transcontinental railway link at Promontory Summit. From then on, the whole of the USA was connected by a network of railroads. While the old, British means of transportation had enabled new storylines, as I explained above, the new, American mobility made reading a necessary activity. "Travelers of the eighteenth century," Wolfgang Schivelbusch wrote in his paradigmatic study of the cultural impact of the railroad, "formed small groups that, for the duration of the journey, were characterized by intensive conversation and interaction [...]. The travelers in the train compartment did not know what to do with each other, and reading became a surrogate for [...] communication [...]." (67)

Once again, a change in transport technology coincides with the emergence of a new literary genre. If the stagecoach had brought about the novel in Britain, then the railway has made possible the emergence of the dime novel in the USA.

In 1860 publisher Irwin P. Beadle began issuing a series he called Beadle's Dime Novels. These were paper-covered booklets, issued at regular intervals (every two weeks or so), and numbered in sequence. (Cox 2007: ix)

The dime novel's success was immediate and unprecedented, as a contemporary observer notes: "A dime novel is issued every month and the series has undoubtedly obtained greater popularity than any other series of works of fiction published in America" (Everett 1864: 304). According to a study by Michael Denning, "Beadle and Adams had published four million dime novels by 1865 ; sales of individual titles ranged from 35,000 to 80,000 " (1987: 11). The dime novel, consequently, meant big money: "Never before or since has bookpublishing held a larger share of the gross national product" (Bleiler 1974: vii). ${ }^{1}$ In the late nineteenth century, when the railway had become the most dominant means of transport, literature, also, had reached the peak of its popularity: dime novels became available to almost everyone, everywhere, at anytime.

Bleiler does not provide any form of prove for this claim, however. 
By the 1870s, the dime novel had become a generic term: "Popularly, the term had little reference to the price at which the booklets were sold, but it was applied especially to any sensational detective or blood-and-thunder novel in pamphlet form" (Johannsen 1950: 3). Nonetheless, the dime novel became a genre defined by its monetary and spatial availability:

Technological advances in printing methods and papermaking made possible the mass production of reading material, while the development of communication and transportation systems made possible the distribution of cheap publications to newsstands in cities and towns or by subscription through the mail. (Cox 2007: ix)

Whereas in eighteenth-century Britain the stagecoach brought together people (from different regions and sections) and novels, the railway in the USA brought together migrants from all over the world and cheap, easy-to-read dime novels. The railway enabled circulation along its networks as much as distribution through station bookstalls. Most of all, however, the railroad became a place to read: "Reading while traveling became almost obligatory," Schivelbusch (64) concludes. While the British novel taught its readers to imagine a possible past of an unknown vis-à-vis, the American dime novel taught its readers to forget about this past and concentrate on the future. Money became the dime novel's model to do so.

\subsection{The Dime}

The mobility of the dime novel was matched only by its eponym. Like the British 'penny dreadfuls,' the dime novel received its name from a coin. With the Coinage Act of 1792 a national currency was established in the US and one specie to be used was the so called "dismes, each to be of the value of one tenth of a dollar or unit, and to contain 37 2/16 grains of pure, or $413 / 5$ grains of standard silver" (Hickcox 1861: 328). From then on, money was to have a standard value all over the United States and could be used for every economic transaction within the USA, anyplace, anytime - and by anyone.

Money, as we all know, plays a decisive role in the formation of modern economy. Before the introduction of money, people were exchanging goods and services. Along the American 'frontier,' this apparently natural state based on subsistence economy and the direct exchange of goods gained a new life that had long disappeared in Europe. However, with new cities and new factories, with new ports and ships, and most importantly: with the establishment of a railroad network, so much more and more diverse goods were circulating that it, quite obviously, became less and less likely that one would find someone who has exactly that which one wants and wants what one has to give. One would, indeed, have to travel up and down the country to find the right person to exchange goods with. That this is hardly practical is obvious, and the problem of exchange in a more diversified and at the same time more connected society became the focus of a whole array of publications explaining the use and worth of money to the American public - just at the time when the dime novel began to rise.

At the beginning of what is sometimes called a 'Second Industrial Revolution,' but which was at least as much a financial revolution, a text simply entitled Money (1863) informs the reader:

A correct appreciation of the functions of money and of the natural laws that govern it, is of vast importance to humanity, from its universal use in the 
exchanges of commodities and services; exchanges becoming each day more numerous and indispensable in consequence of the constantly increasing division of labor. (Moran 1863: 7)

In modern economy, only one party receives the good she or he wants - the other party gets only money to buy what she or he wants at a later stage. However, and this is the important part, the gratification of one's needs and wishes is not only deferred in the process of exchange; more importantly, money transforms the personal relation one may have formed to a certain good - for example through one's labor invested or the object's place and time of origin - into a multitude of possible acquisitions. In order to do so, money has to erase the differences between goods with different origins and make them comparable and exchangeable: money, consequently, is de-personalizing, de-contextualizing and dehistoricizing (cf. Luhmann 1988: 18). For a payment to open those future possibilities that compensate the seller for relinquishing a good, money is free of all connotations formerly attached to a good. Money, consequently, is open to all, irrespective of the social or regional background of the goods they are supposed to represent; money, therefore, forms the basis for a mobile modernity.

At the time when the modern novel first emerged, Daniel Defoe, in his paradigmatic conduct book for the Complete English Tradesman, has ingeniously described how a new form of writing had to be found to supplement the work of money and make trans-regional and trans-communal exchange (of goods) possible. Advising on how to write a letter to a business partner, he instructs the aspiring tradesman:

If any man were to ask me, what I would suppose to be a perfect style, or language, I would answer, that in which a man speaking to five hundred people, all of common and various capacities, should be understood by them all. (Defoe 2007: 19)

The dime novel, like the dime, manages exactly this: to speak to a great amount of people, all of common and various capacities, and be understood by all of them. A common language, free of the specialized lingo of organizations and function systems and understandable to migrants from various, but often low social backgrounds, is a necessary condition for the popularity - and that means great regional and social diffusion - of the (dime) novel. It is, however, not sufficient. The easily accessible language of popular literature can only explain why many could read these texts, not why they should decide to actually do so. The British novel invented ever-new characters from Robinson Crusoe and Pamela to David Copperfield and Oliver Twist, with which readers could identify, to make people read stories and learn how to plot life-stories. Without such innovative characters, novels found it hard to succeed. The dime novel, finally, invented an ingenious character that could be used again and again: the detective.

\subsection{The Detective}

The it-narratives of the eighteenth century, as mentioned above, had only little success. The reason for this lack of popularity, I assume, is the fact that while they managed to achieve the mobility that is necessary for a plot, they failed in providing a character one would want to follow through various encounters. The more successful novels of the eighteenth and 
nineteenth century managed to create characters that readers loved to follow; however, as the characters were regionally and/or socially situated, the potential readership was often limited along similar lines. And even if the characters were universally popular, their specificity meant that they could only be used once; sequels are rarely successful as the character's potential is usually fully realized at the end of a story. Other than money, novel characters cannot leave behind their social and geographical origins.

The dime novel, however, succeeded in creating a character like a coin: a human that knows no limits, the prosopopoeia of total mobility. This character is the dime novel detective, appealing to an audience without social or regional limitations. Following the success of the free-ranging and wholly independent cowboys and adventurers of earlier tales, the detective became the most important protagonist of the dime novel until its demise towards the end of the century (Harvey 1907: 41; Johannsen 1950: 3-4) - when the car and the cinema started to dominate culture and transportation.

The dime novel detectives not only investigate various cases of stolen money, they behave like money themselves. The adaptiveness of money, necessary for its mobility, finds its equivalent in the detective's mastery of disguise. In this respect, a paradigmatic example of the dime novel detective is Nick Carter (cf. Hoppenstand 1982: 4; Sampson 1983: 85). In what is probably his first appearance, the detective is introduced as follows:

Old Sim Carter [Nick Carter's father; C.H.] has made the physical development of his son one of the studies of his life. Only one of the studies, however. Young Nick's mind was stored with knowledge - knowledge of a peculiar sort. His gray eye had, like an Indian's, been trained to take in minutest details fresh for use. His rich, full voice could run the gamut of sounds, from an old woman's broken, querulous squeak to the deep, hoarse notes of a burly ruffian. And his handsome face could, in an instant, be distorted into any ugliness. He was a master of disguise, and could so transform himself that even Old Sim could not recognize him. (Anonymous 1886: 4)

While Carter's physical and cognitive abilities appear limitless, they are nonetheless topped by his powers of transformation. His ability to become someone else is so absolute that he cuts every tie with his past: even his father does not recognize him. For young Carter, only the future counts: he reads his environment for "minutest details fresh for use."

Like money, the dime novel detective is de-personalized, de-contextualized and dehistoricized. Because Carter is freed of all marks of specificity, of locality, he is enabled to become whom he wants - and to move about freely. Carter mainly works in New York, a cosmopolitan world in miniature, but his liberation from recognition and his ability to adopt any personality and adapt to every situation at will allows him to investigate in every corner of the USA, easily accessible by the trains he uses frequently in almost every episode. ${ }^{2} \mathrm{He}$ roams the streets of Manhattan from Washington Street and the City Hall Park on the Lower West, via Chinatown to the Bowery, and further up to Madison Square, Grand Central Station and Central Park just as easily as he roams the surrounding towns in New Jersey and New York State: Albany, Buffalo, Syracuse, Newark, Lyons, Port Byron, Orange, Milburn, etc. Nor is he restricted to the Northeast. His activities expand to New Smyrna in Florida, to

I am indebted to my research students Benjamin Frahm and Andreas Walter for tracking the movements of Nick Carter through fourteen dime novels from the first series bearing Carter's name: Nick Carter Detective Library. The following conclusions are based on their findings. 
Chicago in Illinois, Sacramento and San Francisco in California, Des Moines in Iowa, Denver in Colorado, Kansas City and St. Louis in Missouri, New Orleans in Louisiana and to rural Nevada. Carter visits all these places in the space of fourteen sixteen-page stories - and wherever he arrives, he overcomes the villain.

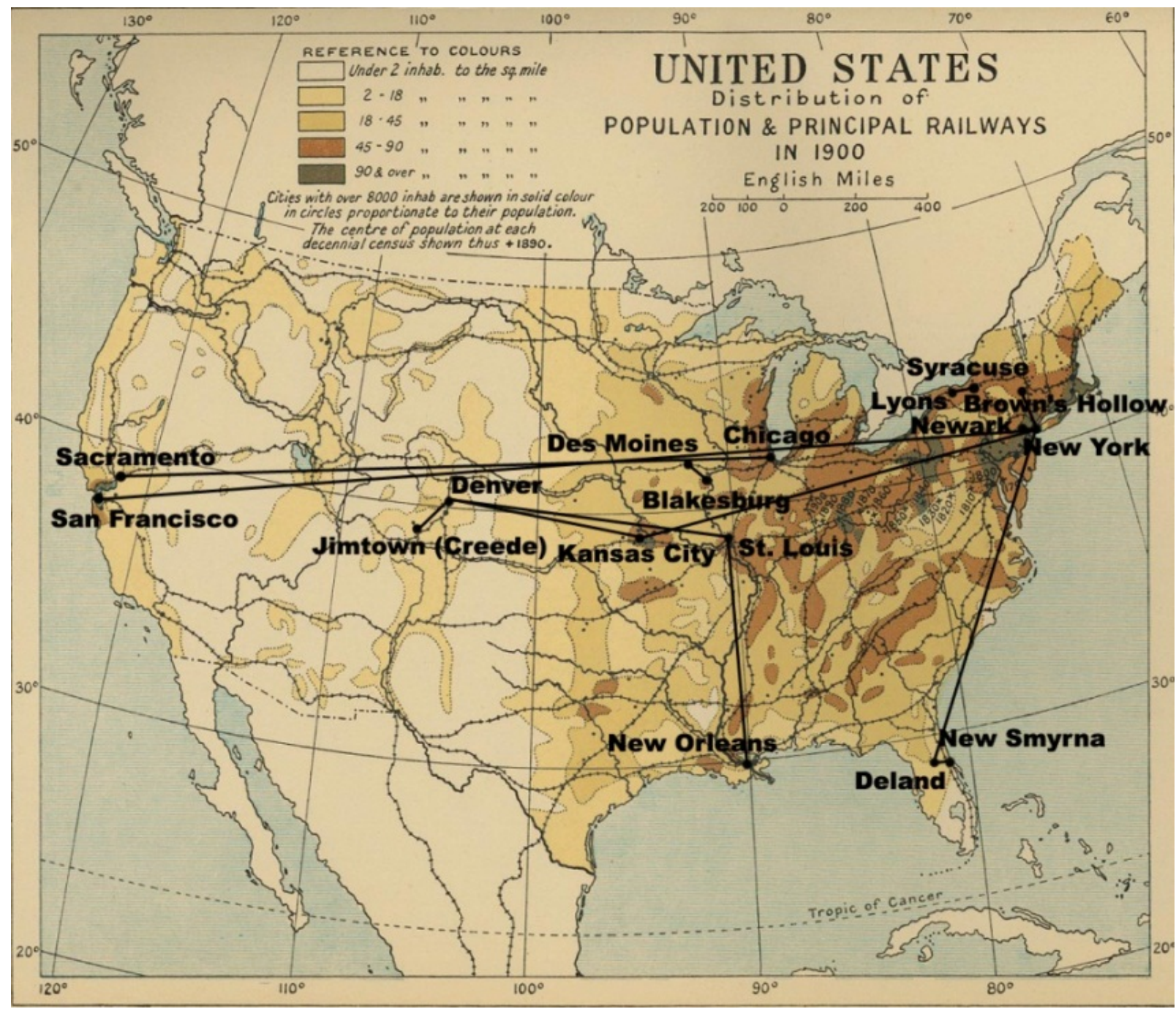

Fig. 1. The Movements of Nick Carter.

The USA, however, did not remain the limit: Nick Carter, in later stories, comes to solve crime in London and Paris, in Japan and Russia, in Nepal, in South America, on a Pacific island and on board of an Atlantic cruise ship. Spatial mobility is supplemented by an ability to move within different social spheres: Carter has little problem behaving appropriately among the upper classes aboard a cruise ship or in the saloons of the Wild West (cf. Cox 1996: 121; Bleiler 1974: 11). His father taught him foreign languages and local customs so that he could remain undetected when undercover in a foreign country (cf. Sampson 1983: 82), or in Chinatown, San Francisco: 
Nick thanked him in the choicest Chinese, and then covertly made a rapid sign of the Suey Sing society. The Chinaman [...] smiled with genuine approval, [...] showing that Nick had been successful in his first venture. (1892: 4)

Like the dime, the dime novel detective can go anywhere and be transformed into anyone barriers of language, class, race or gender seem not to exist for money and detective. As a contemporary observer notes:

He is great in disguises, and on the front page of the volumes describing his adventures are pictures of himself as he appears variously gotten up as a Chinaman, a dude, an old woman, a young man, a rural hayseed, a tough an a negro. (Bache 1893: n.p.)

Although disguises are central to most dime novels (cf. Söndgerath 1985: 196), and indeed many forms of literature, Carter is probably the first to appear almost exclusively in disguise:

Nick Carter was at home when the inspector called, and he received him as he would have received no other man in the whole city of new York; in his own proper person. One of the cardinal points of Nick's faith in himself was that by keeping himself entirely unknown to everybody his various disguises were rendered absolutely impenetrable. (Anonymous 1891:2)

Indeed, there does not seem to be a single story where Carter is not disguising himself at least twice (cf. Gremler 2010: 44). Nick Carter is many. Like the dime, the dime novel detective is not associated with his (social) origins (Söndgerath 1985: 221), but free to become whom he wants. And even the depictions of Carter on the front cover are obscure as to the 'real' appearance of the detective (fig. 2). ${ }^{3}$

That this unmarked everyman is, of course, "a young, muscular, white Anglo-Saxon man" (Denning 1987: 205) separates him from those who are marked by their ethnicity, their gender, their sexuality, their age etc.; while the latter are attributed with roles against their volition, the former takes on these roles at will. The dime, similarly, is only clean in the hands of a white man; in others' hands it becomes money that has to be laundered. 


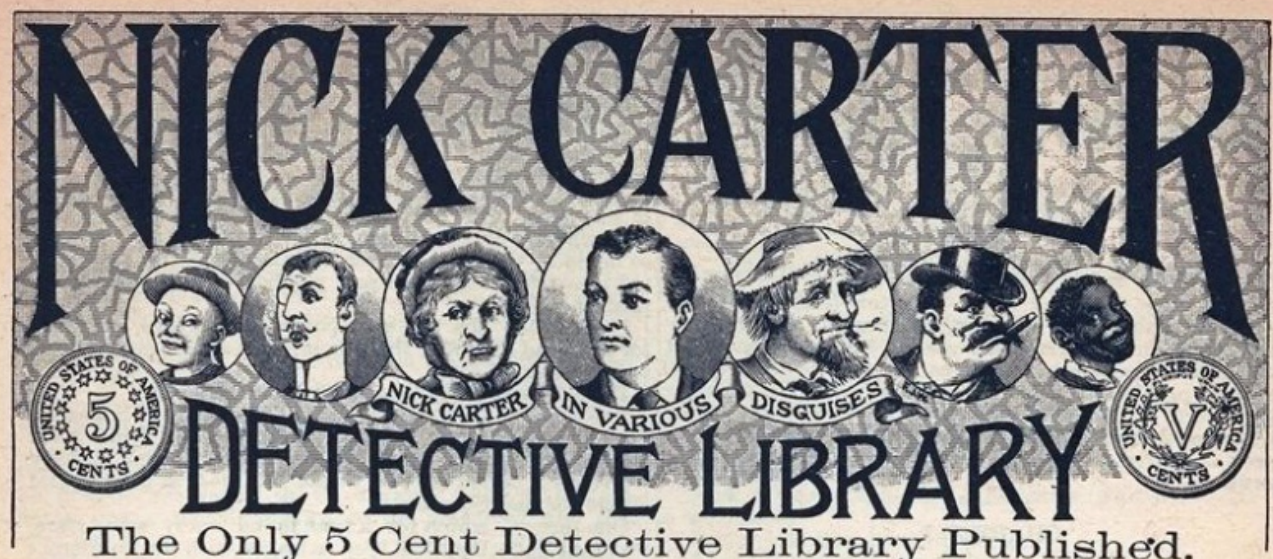

The Only 5 Cent Detective Library Published.

\begin{tabular}{|c|c|c|c|}
\hline No. I. & StRkgr \& BMrti, Publishers, & NEW YORK. & 31 Rose St., N. Y. P. O. Box 273 . \\
\hline
\end{tabular}
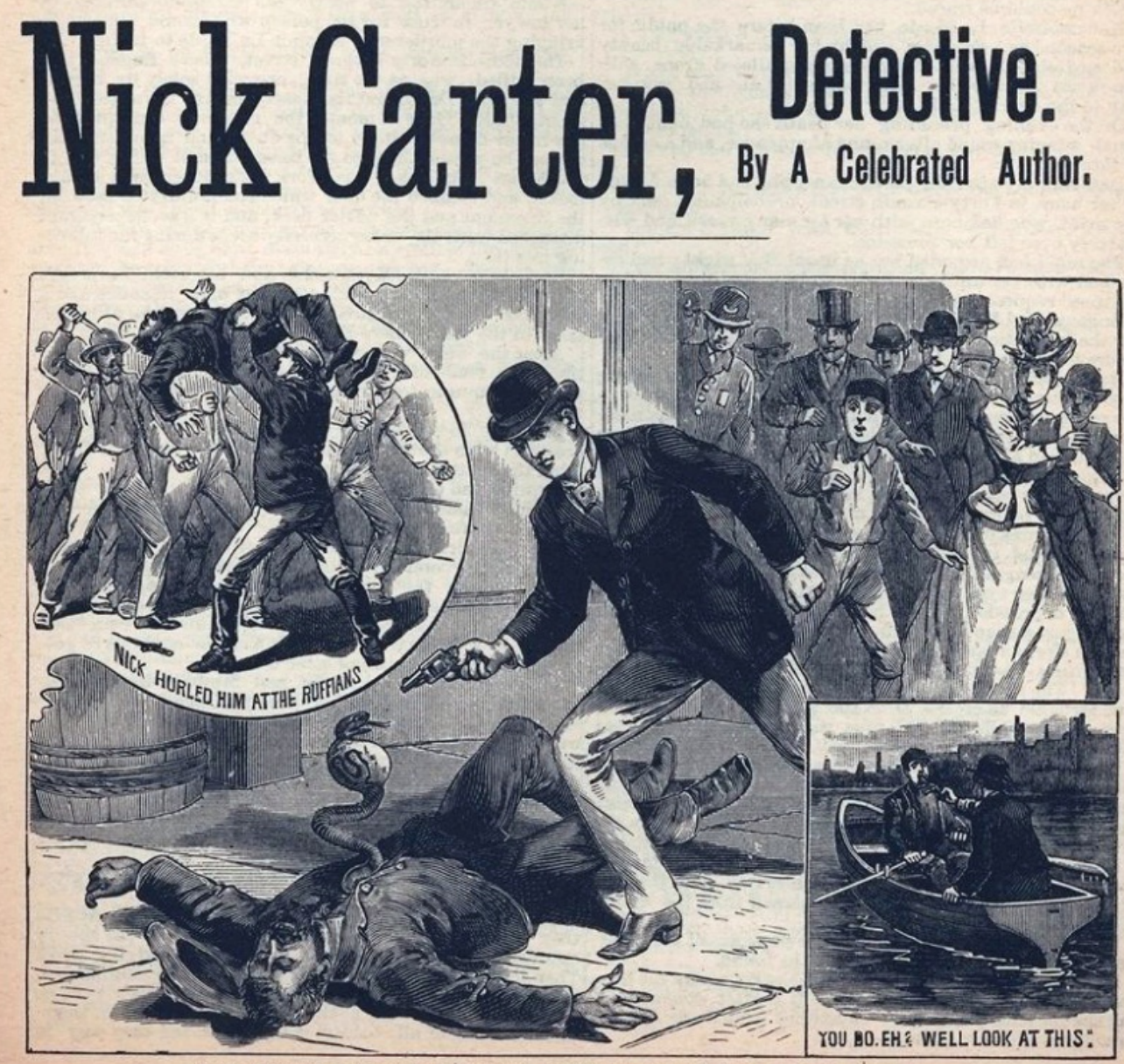

NICK LEANED FORWARD AND TOOK CAREYUL AIM AT THE DEADLY COBRA.

Fig. 2. Nick Carter Detective Library, No. 1 (1891). 


\section{The World Wide Detective}

Siegfried Kracauer, who analyzed the German adaptations of the dime novel - the so-called Groschenhefte - in the 1920s, also highlighted the significantly insignificant appearance of the dime novel detective:

Glattrasiertes Gesicht, dessen smarte Züge, abgesehen von ihrer Prägung durch den Intellekt, der Eigenbedeutung entbehren, 'trainierter Sportsmannskörper, beherrschte Bewegungen' [...]; ferner unauffälliges Benehmen und Kleidung nach der Mode und den Umständen: dies ist die typische Erscheinung des Detektivs.

Clean-shaven face, the smart features of which have no meaning of their own, apart from the imprint of intellect, "the trained body of a sportsman, controlled movement' $[\ldots]$; furthermore, inconspicuous behaviour and clothes following fashion and circumstance: this is the typical appearance of the detective.

(Kracauer 1979: 53)

Like the coin that leaves behind the body of those material goods it represents, the detective is disembodied; he is, of course, strong and wins every fight - but his body has no life of its own. Carter, for example, is never ill, never weak and never eroticized. He hardly drinks, he does not do drugs, he does not swear and he does not have sex:

Der Detektiv wird daher als ein Neutrum begriffen, das sowenig erotisch ist wie unerotisch, als ein unaffizierbares 'Es', dessen Sächlichkeit sich aus der Sachlichkeit eines Intellekts erklärt, der durch nichts beeinflußbar ist, weil er gründet im Nichts.

The detective, therefore, is understood as a neuter that is neither erotic nor unerotic, but an unaffectable 'It', whose neutrality is explained by the objectivity of an intellect that cannot be influenced by anything, as it is founded on nothing.

(Kracauer 1979: 59)

In a word: the detective plays it cool in order to reveal nothing of himself (cf. Söndgerath 1985: 203-5). The detective has to be a no-body to become everybody, he has to be a nobody to go where no one else can go: everywhere.

The dime novel detective becomes the prosopopoeia of total mobility, a total mobility that in a modern, globalised society is otherwise only achieved by money. To make this total mobility possible, the detective has to be without history, without individual desires and recognizable features. For the dime novel detective, every place becomes the same: a crime scene - the place where an investigation has to begin. A consequence of this homogenization of space, which many critics of the dime novel have criticized, is the formulaic nature of its plots. If we follow Jurij Lotman, an event, the basic component of a story, takes place if, and only if, a character crosses the limits of a (semantic) space (2006: 535). While most eighteenth-century novels, and especially the above-mentioned it-narratives, revel in the transgression of such borders, the dime novel knows no more than the distinction between a daylight world of respectable people, and the dark underground of crime. Consequently, its plots are little more than variations of the passage from darkness to light. And while the evil thoughts of various criminals are revealed at the end of every story, the detective remains the 
same through hundreds of episodes and dozens of years. His character cannot develop, as he is nobody. His mobility, his transgressions of spatial limits when he hunts down criminals, is without consequence - as he is insignificant, semantic fields have no influence upon him.

That the dime novel detective can investigate everywhere is a specific achievement of the dime novel detective. When Charles Warren Adams, Wilkie Collins and others formed the detective novel from the remnants of the classical mid-nineteenth-century novel, their investigators did a one-off job. In Collins' The Moonstone, a cousin and suitor to the injured party, Franklin Blake, solves the mystery for his own good, that is, to be happily married ever after. A number of dime novel publishers tried to follow this lead, but with little success. Instead, the serial detective became the most successful form of publication. Like money, the serial dime novel detectives can be employed again and again: after their job is done, they are freed for new appointments (cf. Hickethier and Lützen 1976: 275) - nothing of the context in which they solved a mystery (or enabled a transaction) applies to the new situation. Where money enables a multitude of possible acquisitions, the dime novel detective makes possible a multitude of possible assignments.

A central consequence of the detective's mobility is the mobility of the publication he appears in. Being indifferent to context and history, Nick Carter stories can easily be translated into various languages: versions in French, Hungarian, German, Swedish, Italian, Spanish, Polish, Russian and other languages followed suit (cf. Cox 2000: xix; Sterk and Conkright 2006). Finally, Nick Carter, the dime novel detective, becomes a detective of everywhere, he becomes a world detective, as a German adaptation proclaims: beginning as "America's Greatest Detective" ('Amerika's grösster Detectiv'), a later series presents him as "The World-Detective" ('Der Weltdetektiv') (fig. 3 \& 4). He has, finally, achieved the total mobility of the dime novel detective: he really is everywhere at once - like money. His global readers are enabled to learn how to find their ways in a globalised world that has only little time to care for its past - and all the more need to act in unknown situations: 'Just do it!' seems to be its message.

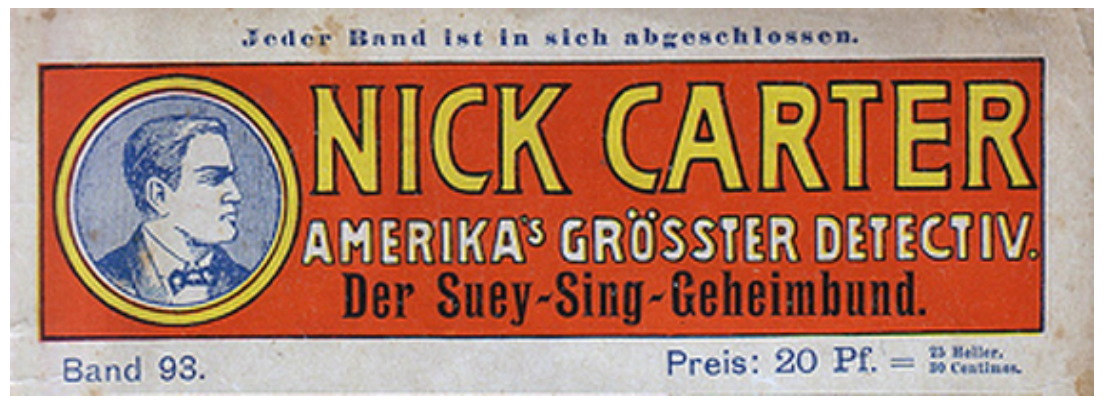

Fig. 3. Nick Carter: Amerika’s grösster Detectiv, Bd. 93: Der Suey-Sing-Geheimbund.

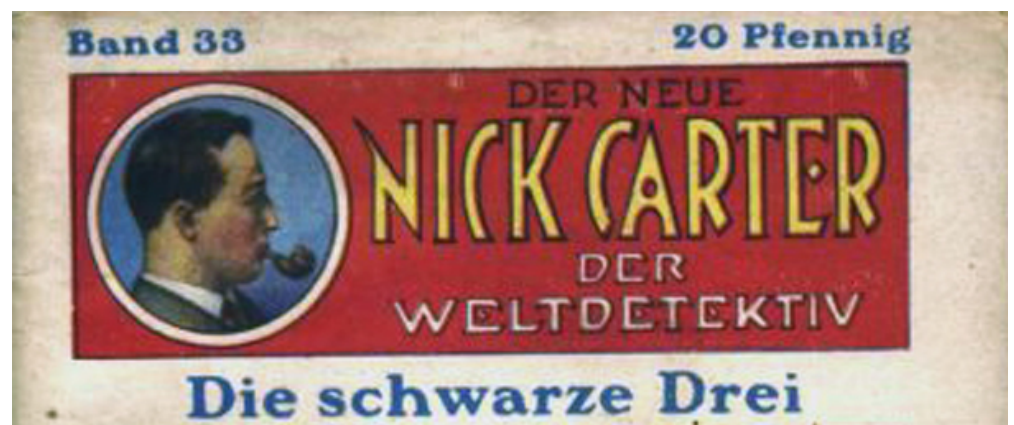

Fig. 4. Der neue Nick Carter: Der Weltdetektiv, Bd. 33: Die schwarze Drei. 
Works Cited

Primary References

Anonymous (1886): “The Old Detective's Pupil.” New York Weekly 40.46.

- (1891): The Solution of A Remarkable Case. New York: Street. Nick Carter Detective Library 1.

- (1892): Nick Carter in San Francisco; Or, Unearthing Crime in Chinatown. New York: Street. Nick Carter Detective Library 26.

Johnstone, Charles (1760): Chrysal: Or, the Adventures of a Guinea. Wherein Are Exhibited Views of Several Striking Scenes, with Curious and Interesting Anecdotes of the Most Noted Persons in Every Rank of Life, Whose Hands It Passed through, in America, England, Holland, Germany and Portugal. Dublin: Dillon Chamberlaine.

Secondary References

Bache, Rene (1893): "The Nickel Novel: Old Sleuth and his Competitors." The Sunday Oregonian 10 Sep. 1893.

Blackwell, Mark (2007): "The It-Narrative and Eighteenth-Century Thing Theory." Introduction. The Secret Life of Things: Animals, Objects, and It-Narratives in Eighteenth-Century England. Ed. Mark Blackwell. Lewisburg: Bucknell UP. 9-14.

Bleiler, Everett F. (1974): Introduction. Eight Dime Novels. Ed. Everett F. Bleiler. New York: Dover. vii-xv.

Cox, J. Randolph (1996): “The Paperback Detective: The Evolution of the Nick Carter Series from Dime Novel to Paperback, 1886-1990." Pioneers, Passionate Ladies and Private Eyes. Ed. Larry E. Sullivan and Lydia Cushman Shurman. New York: Haworth. 119-31.

- (2000): The Dime Novel Companion: A Source Book. Westport: Greenwood.

- (2007): Introduction. Dashing Diamond Dick and Other Classic Dime Novels. Ed. Randolph J. Cox. New York: Penguin. ix-xxix.

Defoe, Daniel (2007): The Complete English Tradesman. Ed. John McVeagh. Vol. 1. London: Pickering \& Chatto.

Denning, Michael (1987): Mechanic Accents: Dime Novels and Working-Class Culture in America. London and New York: Verso.

Everett, William (1864): “Critical Notices: Beadle's Dime Books.” North American Review 99 (July): 303-09.

Gremler, Martina (2010): Ermittlung in Buch und Film - Die Darstellung der Detektion in Sherlock Holmes, Nick Carter, CSI und Waking the Dead. MA thesis ChristianAlbrechts-University of Kiel.

Harvey, Charles M. (1907): "The Dime Novel in American Life." The Atlantic Monthly 100: 37-45.

Heyl, Christoph (2004): A Passion for Privacy: Untersuchungen zur Genese der bürgerlichen Privatsphäre in London, 1660-1800. Munich: Oldenbourg.

Hickcox, John H. (1861): "The History of American Coinage. Part 2." The Bankers' Magazine XI.5: 321-37. 
Hickethier, Knut, and Wolf Dieter Lützen (1976): "Der Kriminalroman: Entstehung und Entwicklung eines Genres in den literarischen Medien." Trivialliteratur. Ed. Annamaria Rucktäschl and Hans Dieter Zimmermann. Munich: Fink. 267-95.

Hoppenstand, Gary (1982): “The Missing Detective." Introduction. The Dime Novel Detective. Ed. Gary Hoppenstand. Bowling Green: Bowling Green U Popular P. 3-4.

Johannsen, Albert (1950): The House of Beadle and Adams and its Dime and Nickel Novels: The Story of a Vanished Literature. Vol. I. Norman: U of Oklahoma P.

Kracauer, Siegfried (1979): Der Detektiv-Roman: Ein philosophischer Traktat. Frankfurt a.M.: Suhrkamp.

Lichtenberg, Georg Christoph (1817): "Über den deutschen Roman." Vermischte Schriften, Erster Theil. Vienna: Kaulfuß. 56-63.

Lotman, Jurij (2006): "Künstlerischer Raum, Sujet und Figur." Raumtheorie: Grundlagentexte aus Philosophie und Kulturwissenschaften. Ed. Jörg Dünne und Stephan Günzel. Frankfurt a.M.: Suhrkamp. 529-43.

Luhmann, Niklas (1988): Die Wirtschaft der Gesellschaft. Frankfurt a.M.: Suhrkamp.

Lynch, Deidre Shauna (2005): "Novels in the World of Moving Goods." A Concise Companion to the Restoration and Eighteenth Century. Ed. Cynthia Wall. Malden, et al.: Blackwell. 121-43.

Moran, Charles (1863): Money. New York: Appleton.

Sampson, Robert (1983): Yesterday's Faces: A Study of Series Characters in the Early Pulp Magazines. Vol I: Glory Figures. Bowling Green: Bowling Green U Popular P.

Schivelbusch, Wolfgang (1979): The Railway Journey: Trains and Travel in the 19th Century. New York: Urizen.

Söndgerath, Franz-Josef (1985): Wandlungen der amerikanischen 'Dime Novels'. Frankfurt a.M. et al.: Lang.

Sterk, Rimmer, and Jim Conkright (2006): The Continental Dime Novel (JCRS).

Illustrations

Anonymous. Nick Carter: Amerika's grösster Detectiv. Der Suey-Sing-Geheimbund. Vol. 93. Dresden: A. Eichler Verlagsbuchhandlung.

- Der neue Nick Carter - Der Weltdetektiv: Die schwarze Drei. Vol. 33. Dresden: A. Eichler Verlagsbuchhandlung.

- (1891): The Solution of a Remarkable Case. New York: Street: Title page. Nick Carter Detective Library 1.

Ward, A. W. (1912): The Cambridge Modern History. Vol. 14: Atlas. Cambridge: Cambridge UP.Map 77. 